\title{
Distinct Features of the Self-Concept and the Meaning-Forming Motives of Intellectual Professionals: A Case of Australian and Russian Specialists of Intellectual Labour
}

\author{
Julia V. Obukhova ${ }^{1 *}$, Ekaterina L. Komarovskaya ${ }^{2}$ \\ 1 Southern Federal University, Rostov-on-Don, Russian Federation \\ 2 DBL Solicitors, Brisbane, Australia \\ *Corresponding author. E-mail: yvobuhova@sfedu.ru
}

\begin{abstract}
Introduction. The authors substantiate the necessity and relevance of studying the features of self-concept and the meaning-forming motives for intellectual labour. The novelty of this study is that a comparative analysis of the particularities of selfconcept and the meaning-forming motives of the Australian and Russian specialists of intellectual labour is carried out for the first time.
\end{abstract}

Methods. The study is based on the survey of 30 Australian and 40 Russian professionals in various fields of intellectual labour, whose average age was 34 years and 36 years old respectively. Psychological testing and content analysis of respondents' selfdescriptions were used as primary methods of research. The questionnaire with openended items created by the authors, entitled "Meaning-Forming Motives of Labour Activity-Money", has been used for data collection. Parametric and nonparametric statistical procedures were carried out in analyses.

Results and Discussion. This section describes the features of cognitive and emotionalevaluative components of self-concept, work-related meaning-forming motives of Australian and Russian professionals in the field of intellectual labour, both men and women. The leading categories in self-descriptions of the respondents are dependent on their nationality and gender. The following features of self-concept were revealed in the study: Australian men describe themselves through their look, Australian womenthrough their hobbies and friendships, Russian women - through their society status and social environment. The obtained results can be used in the development of a general management system and of training programs for professionals in the field of intellectual labour.

\section{Keywords}

self-concept, self-attitude, meaning-forming motives, features, work, money, process, result, intellectual labour force, Russian employees, Australian employees 


\section{Highlights}

- "Personality" category is predominant in the cognitive component of self-concept of Australian women and Russian men.

- Regardless of gender or nationality, self-relation of professionals in the field of intellectual labour is subjective.

- Differences were discovered in the degree of severity of the participants' meaningforming motives depending on their gender and nationality.

- Differences were also found in the influence of the work meaning-forming motives on the cognitive component of the participants' self-concept, depending on their gender and nationality.

\section{For citation}

Obukhova J. V., Komarovskaya E. L. Distinct Features of the Self-Concept and the MeaningForming Motives of Intellectual Professionals: A Case of Australian and Russian Specialists of Intellectual Labour. Rossiiskii psikhologicheskii zhurnal - Russian Psychological Journal, 2018, V. 15, no. 3, pp. 143-159. DOI: 10.21702/rpj.2018.3.7

Original manuscript received 02.07.2018

\section{Introduction}

In the modern market, personnel capable of applying new technologies to their work, processing large amounts of information, creating and implementing innovations is a leading factor in defining profitability and competitiveness of the organisation. Intellectual work is a complex process, requiring an employee not only to possess high level of IQ, well-developed verbal, social and emotional intelligence, professional knowledge and skills, but also to understand their own strengths and weaknesses, develop initiative, determination, sociability, dedication, etc. Therefore, the system of motivating of the intellectual workers in the organisation is an important component of the management system. Disclosure of the whole potential of an employee while performing work and optimization of working conditions will not only help to increase productivity and success, but also self-improvement and self-development of the employees of the organisation.

The foreign literature provides an array of strategies for organisations to use in seeking to help motivate their employees. Motives based on external rewards are explained through the individual's cognition of the rewards obtained. The central tenet to these theories is an employee's desire to adjust or regulate his or her behavior based on the satisfaction with the rewards [1]. Adams' Equity Theory proposes that individuals are motivated when they perceive that they are treated equitably in comparison to others within the organisation [2]. Vroom's 


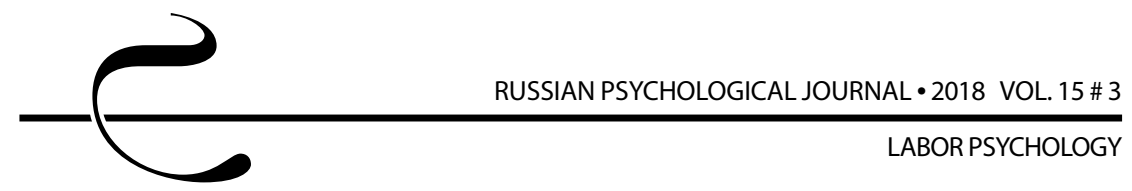

Expectancy Theory addresses to the expectations of individuals and hypothesises that they are motivated by performance and the expected outcomes of their own behaviour [3]. Locke's Goal Setting Theory hypothesizes that by establishing goals, individuals are motivated to take actions to achieve those goals [4]. Ouchi's Theory $Z$ is rooted in the idea that employees who are involved in and committed to an organisation will be motivated to increase productivity. This theory provides for rewards, such long-term employment leaves, promotion etc. to motivate employees [5].

According to the theory of internal motivation that work is a part of life that has strong connections to employee's feelings and emotions. These factors are correlated with the life motives and employee's existence within the organisation [6].

While all of these theories are helpful in understanding management and motivation from a conceptual perspective, it is important to recognise what combination of needs, extrinsic factors and intrinsic factors motivate the specialists of intellectual labour, help them to meet their own personal needs and obligations and ultimately to achieve effectiveness and balance within the organisation.

We will consider a number of researches that will reveal the various aspects of employees' labour motivation. In their study, P.J. Hartung and C.D. Marco noted that the active, determined and persevering employees perceive themselves as capable of making and implementing decisions about career goals and are more competitive and valuable for the organisation [7]. The importance of purposefulness, the ability to set goals for long time perspective, the awareness of their internal resources, planning of external resources and ways to obtain them, professional mobility of the employees for the prosperity of the company are emphasised in the article of N. Dries, R. Pepermans [8]. R.D. Duffy notes in his study that increasing the adaptability of employees, openness in the acquisition of new knowledge, the acquisition of experience, the adequacy of self-esteem, the flexibility to build communication with others, rapid adaptation in a changing environment are of primary importance for the successfully functioning organisation [9].

M.V. Prokhorova in her article discusses the features of external and internal motivations of intellectual professionals, both women and men, their readiness to work at different stages of organisation's development. She empirically established the following patterns: the resulting orientation predominates over the procedural for both men and women employees. Utilitarianism and cooperation are dominant meaningful motives for women employees, and competition and achievements - for men. Competition and communication categories are less pronounced meaning-sense work motives for women, communication - for men [10]. It was revealed that men are more likely to work at the stages of formation and recession of business than women. Men are more focused on 
higher wages than women, it is important for them to have some career prospects. For women, unlike men, a positive work environment is more important [10].

In the study of E. M. Makoto, it was established that cooperation and competition motivation as a result is more expressed towards the team and work. Uilitarian motive in relation to money and achievement motivation with respect to labour have also high indicators. According to the executives, there is a tendency of employees not to help others, but to the contrary, they often pursue their own interests [11]. The revealed pattern can affect the efficiency of the entire organisation as a whole.

The studies of V.P. Musina noted that not only material component of the work performance affects the positive motivation and the level of loyalty of managers of organisation, but also satisfaction of their needs for self-improvement, development of oneself as a specialist and as a person, ability to set and achieve complex goals, creative approach to the duties performed, etc. [12].

The study of A.S. Khodosevich, who studied service workers, showed that women, in the contrary to men, choose their place of work more consciously. Men are less focused on the developing of their competence within the framework of their profession, skills and abilities. More than that, they want to manage and integrate the efforts of other people. As for women, the stability in the workplace is as important as the possibility of self-realisation in other various areas of life [13]. I. L. Maliborskaya shares a similar viewpoint in relation to women [14]. The article written by S.M. Clearfield is devoted to the description of the professional image of social workers from the three chapters of National Association of Social Workers (NASW). Professional self-esteem is defined as an evaluation of a professional group by the members of this group, including opinions about the group's prestige in the society, the value of the profession for the society, personal and behavioral characteristics of each member of the group, their professional capabilities and achievement [15].

In the article of T. Amania-Kepuladze it has been emphasised that the work motives of the employees depend not only on the gender, but on the personal and professional qualities, and it does not always correspond with the accepted stereotypes [16]. J.V. Obukhova, who studied doctors, revealed that the specificity of the meaning-sense motives of work activity varies depending on the gender, age and length of service of the employees [17]. In the study of the Chinese scientists, B. Guo, L. Zhao, etc., it was revealed that for junior nurses the increase of professional self-efficacy is an important meaning-sense work motive [18].

The following conclusions were reach on the basis of meta-analysis conducted by D. Kooij, A. Lange, P. Jansen, R. Kanfer, J. Dikkers: work motives are closely related to the age of the workers, therefore the companies should adjust their $\mathrm{HR}$ policies and methods to match the needs of their employees depending on 
their ages. With age, the internal motivation for success, sense of recognition and autonomy, interesting work and the desire to be a mentor for someone become more important for the senior professionals compared to the junior specialists. So, instead of simply offering a limited opportunity for training and development to the senior specialists, managers need to guarantee them interesting, where they can perform the tasks that would correspond with their qualification and work experience [19]. It is also important to reduce competition and social tension between senior and junior professionals for their respective jobs.

It should be noted that studies describing the characteristics of work motivation of intellectual specialists are not sufficiently described in the modern psychological literature. Most often, it is the employer's point of view on the motivation of employees of intellectual work that is described [20,21], or there is no comparative analysis between the features of intellectual specialists' motivation with the specialists of other professions [22].

In the theses of L.N. Deputatova it was shown that a system to motive Russian specialists for intellectual activity should include four directions: increase of intellectual potential, effective communication, increase of competence, increase productivity at work. To create the conditions for the development and implementation of intellectual labour, an effective system of organization is needed, including a unit for the development of intellectual potential, development of communications and a unit for motivating employees. The main activities for the development of the organisation's intellectual capital must be implemented through the organisational culture development programs, continuing education programs, personnel selection procedures, employees and their families health programs. The work motivation system of the Russian organisations' employees should be aimed at improving of the quality of the intellectual work results, increasing the competencies of the employees, effective communication and growth of the intellectual capital of the enterprise [23].

$\mathrm{N}$. H. Leonard et al. introduced the self-concept as a source of motivated behaviour, in their study noted that a social self-concept of female employees is chronically activated, and female employees are motivated to behave in ways to meet the expectations of others and elicit social feedback that is consistent with their self-concept perceptions. The female employees behave in ways that satisfy reference group members, first to gain acceptance and, after achieving that, to gain status [24]. Findings suggest that both male and female employees of intellectual labour who choose goals that are consistent with their own ideals, personal interests, and values are happier than those who pursue goals for other reasons [25].

E.M. Hallowell suggests that managers can help to motivate the employees of intellectual labour by encouraging them to eat right, exercise regularly, take vacations, get organised and slow down [26]. Such external rewards as perceived 
fairness of rewards and financial incentives were also found to be motivating. Their study concluded that designing flexible incentives, adjusted to the employees' needs is most motivating to the employees [27].

T.A. Atchison discusses in his study egocentric and other-centered satisfaction and suggests that in the short run employees respond to specific rewards that they receive personally but in the long term they respond to quality performance of the team and the organisation. Atchison stated that money motivates only to a certain point. That is when compensation is not high enough, or is considered to be inequitable, it demotivates the intellectual workers. In contrast, when it is proportionate to the input in the employees' view, it is a great motivation to increase productivity [28].

B. Schmid \& J. Adams identified factors affecting employee motivation from a sample of 115 intellectual professionals in Australia. External motivating factors such as providing feedback on employee's performance and ease of communication between the team members is motivating to the employees [29].

On internal rewards, G. Hertel, S. Niedner \& S. Hermann [30], and more recently H.N. Sharp, et al. [31] and S. Seiler, et al. [32] suggest that the nature of tasks, autonomy at work and task significance are more motivating for male employees than financial rewards. Similar results were also suggested by R. Dwivedula and C. Bredillet. Opportunities to apply advanced knowledge and perform competency-enhancing tasks are perceived to be motivating by male employees of intellectual labour [33].

J.A. Rose stated in his study that the operative method of entailing recognition, evaluation, setting of priorities and articulation of the firm's values in a dayby-day and layer-by-layer manner is an important motivation for both male and female employees by acknowledging the employees' presence and input as vital components in the process. Self-motivation for male employees is the most significant component of motivation towards contribution to the success of the firm. In the light of this, the organisation's primary function must limit any interference with the self-motivated potential. The firm may encourage selfmotivation. The most important factor expressed by J.A. Rose in motivating the female employees is creation by the organisation a friendly non-confrontational environment that leads to firm identification and allegiance by cultivating and enabling the female employee's active participation in the firm's affairs through involvement, input, responsibility, communication, and professional growth [34].

We note that Russian and foreign studies accumulated a substantial material on the certain aspects of the self-concept, however, a connection with the work meaning-sense motives is lacking. The interrelationship between gender and professional images of the female leaders is described in the study of N.N. Lupenko [35]. Levels of gender and professional self-esteem of servicemen and 


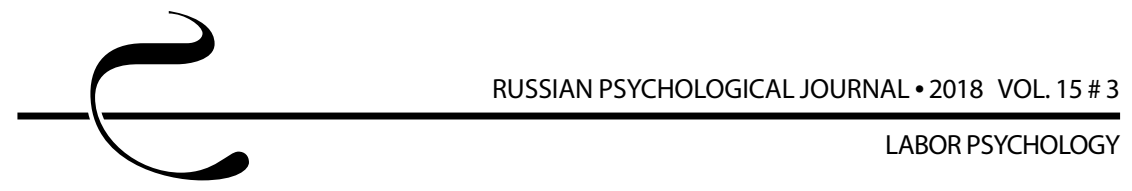

sales managers are described in the study of L.N. Ozhigova and N.N. Lupenko [36]. The dynamics of the professional self-concept at the initial stages of becoming a psychologist is described in an article of E.V. Belova [37]. S.T. Djaner'yan distinguishes the structure of the professional self-concept types [38].

\section{Methods}

All the above shows the relevance of this study, the purpose of which is to explore the self-concept peculiarities and the the meaning-sense motives of intellectual work activity. Subject of research: self-concept and meaning-sense motives of work.

The study involved 30 Australian people ( 10 men and 20 women aged from 24 to 53 years, average age -34 years) and 40 Russian people (20 men and 20 women from 28 to 55 years, average age -36 years), the professionals of intellectual labour. All participating companies are medium-sized management consulting and engineering companies located in the cities of Brisbane (Australia) and Rostov-on-Don (Russia).

Anonymous testing was used as a tool for collection of information from the specialists of intellectual labour - employees of several Australian and Russian companies. After the successful negotiations with the top management of those organisations, a brief explanatory letter and testing materials were sent to the employees' corporate emails. Participation in the study was voluntary, there was no pressure observed from the management.

The following methodological tools were used: the questionnaire "The meaningmaking motives of labour activity - money" (based on the meaning-sense motives highlighted in the questionnaire "Dictionary" of I.G. Kokurina) [39], with free selfdescription. For Australian respondents the questionnaire was provided in English language, for Russian respondents - in Russian. In that questionnaire it was necessary to rank money, as a meaning-sense motive of work activity, in order of importance to the respondent, with the most important to be number 1, the least important -12 .

The following the special research methods were used: content analysis of self-descriptions, expert assessments of indicators of self-description categories. Statistical data processing methods were applied (Normal Probability Plot, multiple linear regression analysis, non-parametric statistics methods such as determination of Spearman's correlation coefficient, Wilcoxon signed-rank test, Mann-Whitney $U$ test, Friedman test). In the first stage, the pilot coding of selfdescriptions was carried out to select the relevant categories. In the second stage, two expert psychologists who are fluent in English and Russian checked the adequacy of the categories' choice and adjusted the selected categories were it was necessary. The relative frequency of occurrence of the category in the self-description was an indicator of its severity. 


\section{Results and Discussion}

Let us discuss the results obtained on the basis of the collected data analysis. We will consider the features of the cognitive component of the Self-concept of Australian specialists of intellectual labour - men and women (Tables 1 and 2).

Table 1. Features of the cognitive component of the Self-concept of Australian specialists of intellectual labour - men

\begin{tabular}{|l|c|c|}
\hline \multicolumn{1}{|c|}{ Categories } & Average Ranks & Sum of Ranks \\
\hline Personality & 4,50 & 45,00 \\
\hline Family & 3,55 & 35,50 \\
\hline Skills & 4,90 & 49,00 \\
\hline Life & 2,75 & 27,50 \\
\hline Career & 3,60 & 36,00 \\
\hline Appearance (look) & 1,70 & 17,00 \\
\hline
\end{tabular}

There is no dominant trait in the cognitive component of the self-concept of Australian male specialists of intellectual labour. All traits are equally expressed. This testifies to the harmonious development of the personality, the vision of oneself in different connections and relations of reality. It was revealed that a great concentration on the spheres of vital activity falls on the features reflected in the "skills" and "personality" categories. When describing themselves, men most often list their skills and abilities, as well as their personal strengths. The appearance description is found in almost every Australian man self-description, but the number of references to other categories is inferior.

Table 2. Features of the cognitive component of the Self-concept of Australian intellectual labour specialists - women

\begin{tabular}{|l|c|c|}
\hline \multicolumn{1}{|c|}{ Categories } & Average Ranks & Sum of Ranks \\
\hline Personality & 6,85 & 137,00 \\
\hline Family & 4,70 & 94,00 \\
\hline Skills & 5,125 & 102,50 \\
\hline Life & 3,82 & 76,50 \\
\hline Career & 4,40 & 88,00 \\
\hline Appearance (look) & 4,225 & 84,50 \\
\hline Friendship & 3,025 & 60,50 \\
\hline Hobby & 3,85 & 77,00 \\
\hline
\end{tabular}


As for the emotional-evaluative component of the self-concept, subjective self-attitude is common for Australian men. They feel that they are an active subject of their lives, have adequate self-esteem, believe in themselves and try to make informed decisions.

In the cognitive component of the Self-concept of Australian female specialists of intellectual labour, the "personality" category prevails by $93.34 \%$ over the "skills" category $(Z=3.098$, with $p=0.00194)$. When describing themselves, women attach great importance to their personal qualities demonstration (both positive and negative). The categories that are least reflected in their self-description are the friendships and hobbies description. Moreover, these categories were selected only by Australian women, and were not found amongst Australian men or Russian workers regardless of gender.

Both subject and object self-relations are common for Australian women. The self-perception of Australian women is heavily dependent on the success or failure in their activities.

Let us turn to an analysis of the results reflecting the peculiarities of the cognitive component of the Self-concept of Russian male and female specialists of intellectual work (Tables 3 and 4).

Table 3. Features of the cognitive component of the self-concept of Russian intellectual labour specialists - men

\begin{tabular}{|l|c|c|}
\hline \multicolumn{1}{|c|}{ Categories } & Average Ranks & Sum of Ranks \\
\hline Personality & 6,15 & 123,00 \\
\hline Life & 3,25 & 65,00 \\
\hline Carrier & 4,30 & 86,00 \\
\hline
\end{tabular}

The category "personality" predominates by $88 \%$ over the "career" category $(Z=2.945$, with $p=0.00134)$ in the cognitive component of the selfconcept of Russian male specialists of intellectual labour. Those men placed more emphasis in their self-description on demonstrating their dedication, sense of duty, sociability and tolerance towards the others. The second place in terms of prevalence is occupied by the "career" category, which includes a description of the professional path, major professional victories and defeats, and the specifics of work. The third place is taken by the "life" category, which includes a description of the social environment, various life circumstances and the ways of dealing with them, as well as skills that enabled the respondents to achieve the desired result. 
Table 4. Features of the cognitive component of the self-concept of Russian intellectual labour specialists - women

\begin{tabular}{|l|c|c|}
\hline \multicolumn{1}{|c|}{ Categories } & Average Ranks & Sum of Ranks \\
\hline Personality & 4,30 & 86,00 \\
\hline Career & 5,80 & 116,00 \\
\hline Status & 5,60 & 112,00 \\
\hline Social environment & 3,50 & 70,00 \\
\hline
\end{tabular}

Russian female specialists of intellectual labour in their cognitive component of the Self-concept do not have a dominant trait, all traits are equally expressed. The leading positions are occupied by the categories "career" and "status", reflecting professional qualities and skills (endowed with analytical mind, selforganisation, ability to clearly set goals and achieve results, etc.), roles in the organisation (indispensable and competent employee, reliable partner, friendly person, etc.), specifics of work environment (assessment of working conditions, relationships in a team, etc.), as well as their social roles (woman, spouse, mother, friend, member of a certain club or association, etc.). Russian female specialists of intellectual work attach special importance to their social environment. Almost in all self-descriptions of those women there is a description of the details necessary for effective work and harmonious life, as well as of people who contribute or, to the contrary, impede with the achievement of the desired results. It should be noted that the status characteristics and social environment were observed only among Russian women and were noted among Russian men and Australian specialists of intellectual labour regardless of their gender. Most often, selfdescription is focused on the present and the future.

Self-attitude is a common characteristic for Russian female specialists. Those women are self-confident, aware of their personality resources and are able to competently manage them, rely only on their strengths.

Having compiled a psychological portrait of our respondents, we proceed to the analysis of the characteristics of their meaning-sense motives of work activity - the attitude towards money. Tables 5 and 6 reflect the results.

For Australian male specialists of intellectual labour, the dominant senseforming motive of work activity (attitude to money) is the resulting communicative motive, and the least pronounced is the procedural motive of achievement. These men seek to earn money to help their families and friends, holding themselves accountable for the general welfare of their family. They do not seek to spend money on their self-improvement, they are more focused on the interests of the other people rather than on their own. Among Australian women, the dominant motive for work (attitude toward money) is the resulting utilitarian motive, and 
the least pronounced is the resulting competing motive. For Australian women, money is needed to meet their needs. They seek to do only what provides them with obvious benefits. It is not important for them to be the best among colleagues, or to have high authority.

Table 5. Features of the meaning-sense motives of labour activity ("money") among Australian specialists of intellectual labour

\begin{tabular}{|l|c|c|c|c|}
\hline \multirow{2}{*}{ Indicators } & \multicolumn{2}{c|}{ Men } & \multicolumn{2}{c|}{ Women } \\
\cline { 2 - 5 } & $\begin{array}{c}\text { Average } \\
\text { Ranks }\end{array}$ & $\begin{array}{c}\text { Sum of } \\
\text { Ranks }\end{array}$ & $\begin{array}{c}\text { Average } \\
\text { Ranks }\end{array}$ & $\begin{array}{c}\text { Sum of } \\
\text { Ranks }\end{array}$ \\
\hline PrR & 5,00 & 50,00 & 6,00 & 120,00 \\
\hline PrP & 6,90 & 69,00 & 5,70 & 114,00 \\
\hline ComR & 2,75 & 27,5 & 5,55 & 111,00 \\
\hline ComP & 4,65 & 46,5 & 4,80 & 96,00 \\
\hline UtR & 4,35 & 43,5 & 4,55 & 91,00 \\
\hline UpP & 8,25 & 82,5 & 4,95 & 99,00 \\
\hline CopR & 7,65 & 76,5 & 7,00 & 140,00 \\
\hline CopP & 9,05 & 90,5 & 5,55 & 111,00 \\
\hline ConR & 7,45 & 74,5 & 10,60 & 212,00 \\
\hline ConP & 7,70 & 77,00 & 9,30 & 186,00 \\
\hline DosR & 4,85 & 48,5 & 7,55 & 151,00 \\
\hline DosP & 9,40 & 94,00 & 6,45 & 129,00 \\
\hline
\end{tabular}

Note: PrP - transforming motive (result), PrP - transforming motive (process), ComR - communicative motive (result), ComP-communicative motive (process), UtR-utilitarian motive (result), UtP-utilitarian motive (process), CopR - cooperation motive (result), CopP - cooperation motive (process), ConR competition motive (result), ConP-competition motive (process), Dos $R$ - achievement motive (result), Dos $P$-achievement motive (process).

For Russian male specialists of intellectual work, the most dominant meaningsense motive for work (attitude towards money) is the procedural motive of achievement, and the least pronounced is the resulting transformative motive.

At the statistically significant level, the prevalence of the procedural achievement motive is typical ( $p=0.0024)$ for Russian men, unlike Australian men. Russian men need money for self-improvement, self-education, for achieving a certain status in society. They are ready to perform even uninteresting work, sacrifice their skills and predisposition to other activities, the main thing for them is that their work should be financial rewarded. 
пСИхОЛОГИЯ ТРУДА

Table 6. Features of the meaning-sense motives for labour activity ("money") among Russian specialists of intellectual labour

\begin{tabular}{|c|c|c|c|c|}
\hline \multirow[b]{2}{*}{ Indicators } & \multicolumn{2}{|c|}{ Men } & \multicolumn{2}{|c|}{ Women } \\
\hline & $\begin{array}{c}\text { Average } \\
\text { Ranks }\end{array}$ & $\begin{array}{l}\text { Sum of } \\
\text { Ranks }\end{array}$ & $\begin{array}{c}\text { Average } \\
\text { Ranks }\end{array}$ & $\begin{array}{l}\text { Sum of } \\
\text { Ranks }\end{array}$ \\
\hline PrR & 8,20 & 164,00 & 4,00 & 80,00 \\
\hline $\operatorname{PrP}$ & 6,80 & 136,00 & 3,70 & 74,00 \\
\hline ComR & 5,60 & 112,00 & 5,50 & 110,00 \\
\hline ComP & 6,40 & 128,00 & 4,20 & 84,00 \\
\hline UtR & 7,10 & 142,00 & 6,30 & 126,00 \\
\hline UpP & 7,30 & 146,00 & 5,90 & 118,00 \\
\hline CopR & 4,50 & 90,00 & 7,10 & 142,00 \\
\hline CopP & 4,50 & 90,00 & 7,20 & 144,00 \\
\hline ConR & 5,30 & 106,0 & 2,65 & 53,00 \\
\hline ConP & 3,60 & 72,00 & 3,30 & 66,00 \\
\hline DosR & 2,80 & 56,00 & 7,40 & 148,00 \\
\hline DosP & 2,35 & 47,00 & 5,50 & 110,00 \\
\hline
\end{tabular}

Note: PrP - transforming motive (result), PrP - transforming motive (process), ComR - communicative motive (result), ComP-communicative motive (process), UtR-utilitarian motive (result), UtP-utilitarian motive (process), CopR - cooperation motive (result), CopP - cooperation motive (process), ConR competition motive (result), Con $P$ - competition motive (process), Dos $R$-achievement motive (result), Dos $P$-achievement motive (process).

For Russian female specialists of intellectual labour, the resulting competition motive is the leading motive-forming motive for work (attitude toward money), whereas the motive for achieving results is the ignored one. Russian women perceive money as confirmation that they are first among the best, that they are successful and respected. They are characterised by a proclaimed competition in the team for the highest prestige. This leads to the unfavorable microclimate in such teams, there is no trust existent among the employees, and conflicts may increase. This pattern was also reflected in the article written by A.V. Sidorenkov, O.Y. Shipitko and other co-authors [40]. 


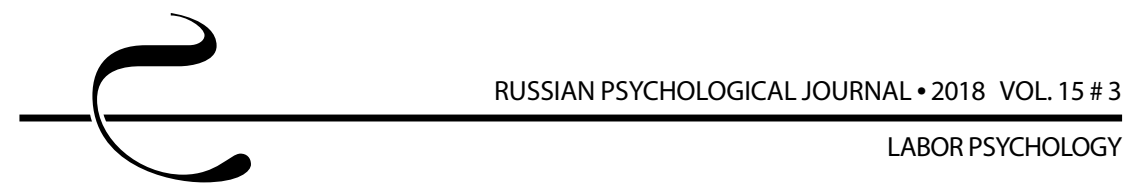

Let us turn to the analysis of influence of the meaning-self motives of labour activity, namely the altitude towards money, on the Self-concept. For Australian male specialists, the resulting communicative motive positively affects the description of oneself through personal qualities whilst the procedural transformative motive affects it negatively $\left(R^{2}=0.816 ; b=0.444\right)$. For Australian men, the description of themselves through life circumstances is positively affected by the procedural cooperative motive and negatively - by the resulting competition motive $\left(R^{2}=0.942 ; b=0.178\right)$.

For Australian female specialists, the description of themselves through personal qualities is influenced positively by the resulting transformative motive, and negatively by the procedural transformative motive of attitude to money $\left(R^{2}=0.668 ; b=0.424\right)$. For Australian women, the resulting transformative motive and the procedural transformative motive have a positive effect on the description of themselves through family roles $\left(R^{2}=0.609 ; b=0.172\right)$.

For Russian male specialists in intellectual work, the description of themselves as professionals ("career" category) is positively influenced by the cooperation motives, both as a result and as a process $\left(\mathrm{R}^{2}=0.578 ; \mathrm{b}=0.0408\right)$. Men, who described their professional skills and peculiarities of their professional way, consider money as remuneration for work performed that is necessary for the society as a whole. For Russian female specialists of intellectual work, the description of themselves as a professional ("career" category) is positively affected by the resulting competing and procedural motive of achievement $\left(\mathrm{R}^{2}=0.548\right.$; $b=0.606)$. Women for whom a career is of a great importance, perceive money as a sign of a high status in society and a resource for self-realisation in various spheres of life.

Considering all the factors we have discussed, we can draw the following conclusions:

1. Features of Self-concept differ from Australian and Russian male and female specialists of intellectual labour.

2. It was established that the expression of the meaning-self motives of labour activity are different for Australian and Russian male and female specialists of intellectual labour.

3. The cognitive component of the Self-concept of Australian and Russian male and female specialists of intellectual work is influenced by different meaningsense motives for work - the attitude towards money.

In our opinion, the reached conclusions can be successfully used in the development of a management system of intellectual work specialists, however, when making individual decisions, undoubtedly, the individual characteristics of employees should be considered. 


\section{References}

1. Bandura A. Social Learning Theory. Prentice-Hall: Engelwood Cliffs, N.J., 1977. $247 \mathrm{p}$.

2. Adams J. S. Towads and understanding of inequity. Journal of Abnormal and Social Psychology, 1963, V. 67 (5), pp. 422-436.

3. Vroom V.H. Work and motivation. San Francisco, CA: Jossey-Bass Inc., 1995. 397 p.

4. Locke E. A. \& Latham G. P. Building a practically useful theory of goal setting and task motivation: a 35-year odyssey. American Psychologist, 2002, V. 57 (9), pp. 705-717.

5. Ouchi W. G. Theory Z: How American business can meet the Japanese challenge. Addision-Wesley, Reading, M.A., 1981. 283 p.

6. Maslow A. Motivation and Personality. N.Y.: Harper \& Row, 1970. 395 p.

7. Hartung P. J., Marco C. D. Refinement and Further Validation of the Decisional Process Inventory. Journal of Career Assessment, 1998, V. 6, Issue 2, pp. 147-162. DOI: 10.1177/106907279800600203

8. Dries N., Pepermans R. "Real” high-potential careers. An empirical study into the perspectives of organizations and high potentials. Personnel Review, 2008, V. 37, Issue 1, pp. 85-108. DOI: 10.1108/00483480810839987

9. Duffy R. D. Sense of Control and Career Adaptability Among Undergraduate Students. Journal of Career Assessment, 2010, V. 18, Issue 4, pp. 420-430. DOI: $10.1177 / 1069072710374587$

10. Prokhorova M. V. Sense-making Work Motives of Women and Men. Izvestiya Saratovskogo universiteta. Novaya seriya. Seriya: Filosofiya. Psixologiya. Pedagogika - Izvestiya Saratov University (N. S.), Ser. Philosophy. Psychology. Pedagogy, 2017, V. 17, Issue 3, pp. 314-318 (in Russian). DOI: 10.18500/18197671-2017-17-3-314-318

11. Makota E. M. Peculiarities of the modern manager the motivation to work Mir nauki, kul 'tury', obrazovaniya - The world of science, culture and education, 2012, no. 4 (35), pp. 245-249 (in Russian).

12. Musina V.P. Experimental study of the problem of diagnostics of professional motivation of managers of a commercial organization. Ucheny'e zapiski Sankt-Peterburgskogo gosudarstvennogo instituta psixologii i social'noj raboty - Scientific notes of the St. Petersburg state Institute of psychology and social work, 2011, V. 16, no. 2, pp. 75-81 (in Russian).

13. Khodosevich A.S. Gender differences in professional standing of personality of the stuff in service industry. Vestnik Tomskogo gosudarstvennogo pedagogicheskogo universiteta - Tomsk State Pedagogical University Bulletin, 2010, no. 4 (94), pp. 146-148 (in Russian).

14. Maliborskaya I. L. Gender characteristics of motivation at different stages of employment. Vestnik Voronezhskogo gosudarstvennogo texnicheskogo 
universiteta - Bulletin of Voronezh State Technical University, 2012, V. 8, no. 10 (2), pp. 178-180 (in Russian).

15. Clearfield S. M. Professional Self-image of the Social Worker: Implications for Social Work Education. Journal of Education for Social Work, 1977, V. 13, Issue 1, pp. 23-30. DOI: 10.1080/00220612.1977.10671409

16. Amania-Kepuladze T. Gender stereotypes and gender feature of job motivation: Differences or similarity? Problems and Perspectives in Management, 2010, V. 8, Issue 2, pp. 84-93.

17. Obukhova Yu. V., Obukhova S. G. Features of physicians' self-concept in connection with the sense-creating motives of their professional activity. Rossiiskii psikhologicheskii zhurnal - Russian Psychological Journal, 2016, V. 13, no. 2, pp. 88-101 (in Russian).

18. Guo B., Zhao L., Gao Y., Peng X., Zhu Y. The status of professional identity and professional self-efficacy of nursing students in China and how the medical documentaries affect them: A quasi-randomized controlled trial. International Journal of Nursing Sciences, 2017, V. 4, Issue 2, pp. 152-157. DOI: $10.1016 /$ j.ijnss.2017.03.006

19. Kooij D. T. A. M., De Lange A. H., Jansen P. G. W., Kanfer R., Dikkers J. S. E. Age and work-related motives: Results of a meta-analysis. Journal of Organizational Behavior, 2011, V. 32, Issue 2, pp. 197-225. DOI: $10.1002 /$ job.665

20. Horwitz F. M., Heng C. T., Quazi H. A. Finders, keepers? Attracting, motivating and retaining knowledge workers. Human Resource Management Journal, 2003, V. 13, Issue 4, pp. 23-44. DOI: 10.1111/j.1748-8583.2003.tb00103.x

21. Horwitz F. M., Albert R. The Horwitz ratio (HorRat): A useful index of method performance with respect to precision. Journal of AOAC International, 2006, V. 89, no. 4, pp. 1095-1099.

22. Kubo I., Saka A. An inquiry into the motivations of knowledge workers in the Japanese financial industry. Journal of Knowledge Management, 2002, V. 6, Issue. 3, pp. 262-271. DOI: 10.1108/13673270210434368

23. Deputatova L. N. Sistema motivacii intellektual'nogo truda rabotnikov (na primere promy'shlenny'x predpriyatij Permskogo kraya) [System of motivation of intellectual work of workers (on the example of industrial enterprises of Perm region]. Diss. Cand. Sci. (Psych.). Perm, 2014. 183 p.

24. Leonard N. H., Beauvais L. L., \& Scholl R. W. Work Motivation: The Incorporation of Self-Concept-Based Processes. Human Relations, 1999, V. 52, Issue 8, pp. 969-998. DOI: 10.1023/A:1016927507008

25. Judge T. A., Bono J. E., Erez A., \& Locke E. A. Core self-evaluations and job and life satisfaction: The role of self-concordance and goal attainment. Journal of Applied Psychology, 2005, V. 90, pp. 257-268. 
26. Hallowell E. M. Overloaded circuits: why smart people underperform. Harward Business Review, 2005, V. 83, pp. 54-62.

27. Rose T. M., \& Manley K. Motivation toward financial incentive goals on construction projects. Journal of Business Research, 2010, V. 64, no. 7, pp. 765-773.

28. Atchison T. A. Exposing the myths of employee satisfaction. Healthcare Executive, 2003, V. 17 (3), pp. 19-20.

29. Schmid B., \& Adams J. Motivation in project management: the project manager's perspective. Project Management Journal, 2008, V. 39, no. 2, pp. 60-71.

30. Hertel G., Niedner S., \& Hermann S. Motivation of software developers in open source projects: An internet-based survey of contributors to the Linux kernel. Research Policy, 2003, V. 32, pp. 1159-1177.

31. Sharp H. N., Baddoo S., Beecham T., Hall T. \& Robinson H. Models of motivation in software engineering, Information and software technology. Information and Software Technology, 2009, V. 51, no. 1, pp. 219-233.

32. Seiler S., Lent B., Pinkowska M., \& Pinazza M. An Integrated Model of Factors Influencing Project Managers' Motivation-Findings from a Swiss Survey. International Journal of Project Management, 2011, V. 30 (1), pp. 60-72.

33. Dwivedula R., \& Bredillet C. The relationship between organizational and professional commitment in the case of project workers: Implications for project management. Academy of Business Research Journal, 2010, V. 41, no. 4, pp. 79-88.

34. Rose J. A. Motivating Attorneys to Accomplish Objectives. Management Consultants to Law Offices, 2017. Available at: http://www.joelarose.com/ articles/motivating_attorneys.html (Accessed 30 June 2018).

35. Lupenko N. N. The relationship of gender and professional images I and the problem of self-actualization of the personality of the head. Izvestiya Possijskogo gosudarstvennogo pedagogicheskogo universiteta im. A. I. GercenaIzvestia: Herzen University Journal of Humanities \& Science, 2008, no. 73-2, pp. 108-112 (in Russian).

36. Ozhegova L. N., Lupenko N. N. Gender and professional self-assessment in men at the first stage of professional development. Obshhestvo: sociologiya, psixologiya, pedagogika - Society: Sociology, Psychology, Pedagogics, 2016, no. 7, pp. 22-24 (in Russian).

37. Belova E. V. Professional'nye predstavleniya lichnosti kak uslovie ee uspeshnogo professional'nogo stanovleniya [Professional representations of the personality as a condition of its successful professional formation]. Professional'nye predstavleniya: sbornik nauchnykh trudov Internet-konferentsii "Znachenie predstavlenii v obrazovanii i professional'nom stanovlenii 
lichnosti" [Professional representations: collection of scientific works of the Internet conference "Value of representations in education and professional formation of the personality"]. No. 6. E. I. Rogov (ed.). Rostov-on-Don, MARCH, 2014. pp. 24-33.

38. Djaneryan S.T.The structure of professional self-conception types. Rossiiskii psikhologicheskii zhurnal - Russian Psychological Journal, 2005, V. 2, no. 3, pp. 78-92 (in Russian).

39. Kokurina I. G. Metodika "Slovar"' [The Technique of "Dictionary"]. Psihologija obshhenija: Jenciklopedicheskij slovar' [Communication Psychology: Dictionary]. A. A. Bodalev (ed.). Moscow Publ., 2011, p. 478.

40. Sidorenkov A. V., Shipitko O. Yu., Ulyanova N. Yu., Obukhova Y.V. Types of Interpersonal Contradictions and Conflicts in Work Groups. The Social Sciences, 2016, V. 11, Issue 29, pp. 6999-7010. Available at: http://medwelljournals. com/abstract/?doi=sscience.2016.6999.7010 (Accessed 30 June 2018). 